\title{
PROBLEMS OF LEGAL REGULATION OF THE STATE SERVICE OF UKRAINE
}

\section{Chebotareva G. V.}

\section{INTRODUCTION}

The state service of Ukraine, which ensures the legality of political decisions, the integrity of the state as an institution, the qualitative level of implementation of constitutional guarantees of citizens through stable and continuous provision of public services, has a special role in the construction of a modern European-style legal state, the approval of a democratic model of public administration. Therefore, the problem of creating an effective system of public service is of special importance today.

The essential paradigm of modern public service (to provide and/or provide modern, high-quality legislative and regulatory services to legal entities and individuals, as well as other professional activities of civil servants in the practical implementation of the tasks and functions of the state; focus on the final result of the activity, not the process; rational organization of the activities of public authorities; increasing the level of profitability of public services; the effectiveness of the functioning of the public service), the state and problems of the current system, the functions and tasks of the public service determine the importance of reforming this public institution, bringing it into line with European standards. These issues are reflected in documentary, scientific and journalistic literature.

\section{The main directions of reforming the Civil service at the present stage}

Public service is an important institution of the modern state. Public service as an independent type of state professional activity emerged in the second half of the XVII century in Europe, in particular in Germany and France. Until today, the institution of public service has evolved into one of the foundations of a democratic legal state, an important guarantee of the effective functioning of the state mechanism. Although there are different variants of public service systems in the world, it is still possible to name the General features (principles) of public service. This is primarily professionalism, apolitical (political neutrality or loyalty), stability (or indefinite) and public funding ${ }^{1}$.

\footnotetext{
${ }^{1}$ Tsurkan M. legal regulation of public service in Ukraine. Features of litigation disputes: monograph. Kharkiv: Pravo, 2010. 216 p.
} 
As you know, in Soviet times, the domestic science of administrative law did not pay due attention to the development of the theory of public service, which subsequently affected the level of scientific support of the process of formation of this institution in Ukraine.

Creation and current state of the Institute of public service in Ukraine. Recall that the Institute of public service in our country was established only after the Declaration of independence. The current Law of Ukraine "on public service" was adopted for the first time in the territory of the former Soviet Union on December 16, 1993 among the fundamental laws of independent Ukraine, which directly concerned the process of development of statehood, the definition of the basic principles of organization and functioning of public authorities. The main provisions of this Law were developed under the influence of the socio-political situation of the then Ukraine, and therefore its main task was actually to create the institution of public service, since Ukraine inherited from the Soviet era the party-nomenclature organization of public service relations.

The adoption of a separate law on public service made it possible to state the fact of the establishment of the Institute of public service in Ukraine. The law established a system of civil service and civil servants ' career, especially a public office, detailed the concept of foster care services, service career, the system of management of the civil service - a special body of management of state service of the Main Directorate of state service under the Cabinet of Ministers of Ukraine (later, Ukraine) and interagency Advisory body - the Coordination Council on state service.

This gives grounds to believe that the current Law "on public service" has largely fulfilled its task of creating and legislative support for the main directions of functioning of the Institute of public service in Ukraine ${ }^{2}$.

However, in the broader context, the implementation of this Law has not produced the expected results. In today's conditions, the civil service has not yet become a democratic and effective organization of public service activities under the control of society, aimed at solving urgent problems facing society and the state.

Therefore, one of the priority areas of administrative reform in Ukraine, along with structural and functional reforms in the sphere of Executive power, is also the reform of public-service relations. The main goals and objectives of the civil service should be the protection of the constitutional order, the protection of human and civil rights and freedoms, ensuring the effective

\footnotetext{
${ }^{2}$ Kravchenko S. state-management reforms: theoretical and methodological justification and directions of implementation: monograph. Kyiv: NAGU, 2008. 296c.
} 
activities of state bodies in accordance with their powers, providing quality administrative (management) services to citizens.

New approaches to the organization of civil servants activities should be approved. It is necessary to establish standards of quality of work of public servants and their behavior in relations with citizens. Today, the main task of civil servants should be to ensure human rights and legitimate interests. It is necessary to develop a new management ideology aimed at updating the administrative culture, forming the readiness of management personnel to make decisions and increase personal responsibility with a focus on serving the interests of society ${ }^{3}$.

The concept of administrative reform in Ukraine provides that the public service should be based on such principles:

- classification of state bodies and positions of civil servants;

- determination of the scope of public service and the status of civil servants;

- competitiveness, objectivity, transparency and publicity in public service and career;

- improving the administrative culture of civil servants and strengthening public confidence in them;

- legal protection and political neutrality in the public service;

- motivating, stimulating and encouraging public servants;

- professional training for the civil service;

- optimization of the public service management structure.

It is necessary to provide for the fullest possible regulation of various types of public service, among which many researchers distinguish: militarized (armed forces) and civil, which has two subspecies: a) civil service in public authorities (that is, what is called public service under the current Law); b) civil service in institutions and organizations (in educational institutions, health care and other budgetary organizations).

It would be best to adopt a generalizing law on public service, which would serve as a methodological Foundation for the legal regulation of public service, and not on its separate form, but for today's "weakness" of the budget, this seems premature.

Therefore, the scope of regulation of the new version of the law on public service should be specified to the public-service relations related to the functioning of public authorities. The main title of the law regulating the issues of public service in its narrow sense can be "on service in public authorities".

\footnotetext{
${ }^{3}$ Kolpakov V. Administrative law of Ukraine: Textbook, third edition, augmented. Kiev, Yurinkom Inter, 2001. 752 p.
} 


\section{Types of public service}

The activities of the state, the functioning of its administrative apparatus are carried out through the civil service, which is a special institution of the modern state. The institution of public service makes the mechanism of the state capable of practically solving any issues in the field of public administration.

The word "service" itself is used in various meanings. Under the service is understood and the type of activity of people, and departmental unit (state security service of the Ministry of internal Affairs), and an independent Agency (State customs service). Considering public service as one of types of paid socially useful activity the legislator, in Art. 1 of the Law of Ukraine "About public service", gives its definition as professional activity of the persons holding positions in public bodies and their office on practical performance of tasks and functions of the state and receiving a salary at the expense of public funds. These persons are civil servants and have the corresponding official powers. Doctrinally, civil servants are often also referred to as employees engaged in social services. Thus, taking into account the currently legalized definition of public service, it is necessary to distinguish between state bodies (in which, mainly, civil servants serve) and state enterprises and institutions, the work in which is not a public service ${ }^{4}$.

Public service is classified into the following types:

a) service in the legislative, Executive and judicial branches;

b) on civil and militarized (paramilitary) service;

c) PA civil and specialized service;

d) on the state (in state bodies and military) and civil (municipal service, service in the state organizations and establishments.

\section{The problems of classification}

The current legislation of Ukraine on public service does not provide for a clear division of public service into types and types. The law of Ukraine "on civil service" (hereinafter - the current Law) applies only to those civil servants who: firstly, serve in the Executive authorities or in the offices of these and other state bodies; secondly, who are assigned the rank of civil servant. That is, the current Law provides for the so-called narrow interpretation of public service.

In a broad sense, civil servants should be considered all persons who: first, work or serve in state bodies or in the apparatus of such bodies; secondly, who are assigned either the rank of a civil servant, or class ranks or military or special ranks; thirdly, who are financed by public funds.

\footnotetext{
${ }^{4}$ Constitution of Ukraine: Adopted by the Verkhovna Rada of Ukraine on June 28, 1996. 1996. No. 30. P. 141.
} 
In the context of the need to reform the public service system in Ukraine, the decision on the division of public service into appropriate types and types becomes extremely relevant ${ }^{5}$.

Although a clear legislative consolidation of the various types and types of Ukrainian civil service has not yet occurred, this does not mean that in our country there are no different components of the civil service. First, in addition to the current Law, there are other laws that actually regulate public service issues in various areas (diplomatic service, sanitary and epidemiological service, police service, etc.). Secondly, a significant part of the persons who are not directly covered by the current Law are classified as civil servants. Thirdly, there is an urgent need to unify the current legislation based on the constitutional principle of separation of state power into the relevant branches (legislative, Executive, judicial) and functional components of public administration.

It is proposed to apply the principle of division of the entire civil service into three types. In addition, there are two main types - civil service and militarized service. Those components of the public service that they cannot be attributed to these two types should be grouped into an intermediate (third) type-specialized. This approach will make it possible to classify the whole set of legal relations arising in the public service by type and species characteristics.

Approaches to classification of types of public service. Recall that various researchers proper to do the division of civil service on civil and militarized. For example, D. Bakhrakh notes that the militarized service is characterized by such signs, different from the civil service: the professional duty of employees of this category is to protect the life and health of people, ensuring the safety of citizens and the established order of management, material values, protection of public order and law and order; the right to enter the civil service of a militarized character are persons who reach the age of eighteen years; special disciplinary statutes, regulations about discipline due to the specific characteristics of official powers militarized civil servants; the civil servants have special conditions of entry on duty, the conditions of its passage, the assignment of military and special ranks, attestation and termination of service; have installed in the special administrative-legal regulations of the special legal status of militarized civil servants; special order of attraction to the "legal responsibility".

${ }^{5}$ Code of Ukraine on administrative offences: Enacted by the Supreme Council Of the Ukrainian SSR from 07.12.1984. Bulletin of the Supreme Rada of the Ukrainian SSR. 1984. Annex to No. 51. P. 1122.

${ }^{6}$ Administrative law of Ukraine. Academic course: Textbook: in 2 t./ Vidpovid. ed. Averyanov: Vol. 1: General part. Kyiv: legal opinion, 2007. 591 c. T. 2: special part. Kyiv: Yuridichna Dumka, 2009. 600 s. 
Quite common is the point of view of V. Averyanov, who proposed legislation to delimit such types of public service:

1) service in organs: viscounts power and apparatus, and also in apparatus Parliament, judicial organs, other public bodies (for example, prosecutors). This is actually an administrative service, or the service of officials;

2) service in state bodies (including some bodies of Executive power), which receives a special legal status, including in the Prosecutor's office, internal Affairs, state security, customs authorities, diplomatic institutions, the armed forces. It is a specialized service;

3) service in various state bodies and their apparatus, which, although it has a support and service orientation, but because of its importance requires a special legal regime within the public service. This is the functioning of the so-called patronage services (conditional patronage service).

Moreover, the author believes that "before the institution of public service should not include the activities of persons who, although they perform the most important state-power functions, but have the status of "political figures" and not "civil servants". These persons include the President of Ukraine, the Prime Minister of Ukraine, members of the government of Ukraine, heads of local state administrations, people's deputies of Ukraine, elected officials of the Parliament, including the Chairman of the Verkhovna Rada of Ukraine. The legal status of these persons should be regulated in detail in separate legislative acts" ${ }^{\prime 7}$.

\section{Problems of legal regulation of behavior and disciplinary responsibility of civil servants}

Implementation of large-scale administrative reform in Ukraine, including improvement of the civil service system, will not give the desired positive result if new approaches to the legal regulation of the behavior of civil servants are not introduced.

The need for legislative regulation of the behavior of civil servants. In the current Law of Ukraine "on civil service" (hereinafter - the current Law), a separate article is devoted to the behavior of civil servants: "Article 5. Ethics of conduct of a public servant", according to which a public servant must:

- conscientiously to forge official duties;

- respect citizens, managers and employees, adhere to a high culture of communication;

- to prevent actions and actions that may harm the interests of the public service or adversely affect the reputation of the public servant.

\footnotetext{
${ }^{7}$ About measures for introduction of the concept of administrative, reform in Ukraine: the Decree of the President of Ukraine No. 810 of 22.07.1998. Official journal of Ukraine. 1999. No. 21. P. 943.
} 
It is clear that the tightening of requirements to the behavior of civil servants should be carried out simultaneously both by the state - by means of law and by society - by means of morality. Therefore, the successful solution of these problems is possible by establishing certain, accurate, understandable and, most importantly, acceptable to modern Ukrainian society moral and ethical requirements for permissible manifestations of behavior of civil servants and their legislative consolidation. The complexity of the practical implementation of this task lies primarily in the identification of those rules of conduct of civil servants that are generally recognized, as well as in solving the problem of the ratio of legal norms and moral and ethical requirements.

Now requirements to behavior exist, but they are scattered on different, mainly by-laws, acts. It seems that it is necessary to focus all the requirements for the behavior of civil servants in one legal act of a codified type ${ }^{8}$.

It will allow, first, to group requirements in concrete norms in interrelation and depending on degree of their public danger; secondly, to establish a certain ratio between moral responsibility and responsibility legal for violation of rules of behavior; thirdly, to improve legal responsibility for violation or non-performance of rules of behavior by civil servants by legislative establishment as General requirements (for all community of officials), and special requirements (for special category of civil servants - officials).

Basic requirements for the behavior of civil servants. We should not forget that it is important to determine what requirements for the behavior of employees should be considered basic. The main are considered such:

- respect for the rule of law in the second activity;

- observance of the moral and ethical requirements of behavior accepted in society;

- prevention of corruption;

- conscientious and professional performance of official duties;

- preservation of state and other secrets protected by law.

Ethical requirements for employees in General and civil servants in particular at different times and in different countries were both fundamentally similar and diametrically opposite. Now in Ukraine the ethical requirements to conduct of civil servant is mainly perceived as an important form of professional ethics, which are a set of moral rules of conduct of civil servants, with which to assess its activities in terms of such values as justice, honesty, conscience, dignity, humanity, compassion, responsibility, professionalism, patriotism and the like.

${ }^{8}$ Code of Ukraine on administrative offences: Enacted by the Supreme Council of the Ukrainian SSR from 07.12.1984. Bulletin of the Supreme Rada of the Ukrainian SSR. 1984. Annex to No. 51. P. 1122. 
In principle, the issue of political loyalty of employees to the political leadership needs to be addressed. Here it is not a question of interference in personal life or restriction by certain limits of Outlook of the employee as the person or the citizen ${ }^{9}$.

A civil servant shall not use his official position to obtain additional income, benefits or other benefits from any legal entities and individuals, both for himself, relatives and friends, and for other persons, and shall not violate restrictions and prohibitions against civil servants established by the anticorruption legislation and the Law of Ukraine "on civil service".

Civil servants are constantly working with a lot of information. Therefore, the behavior of a civil servant to preserve state and other secrets protected by law is one of the most important objects of regulation. As a rule, a state employee is prohibited from disclosing state secrets entrusted to him in connection with the performance of official powers, other information with limited access, including after leaving the state service. This question is quite controversial, but its very formulation, in our opinion, is correct. Therefore, we propose to set a period for non-disclosure of state or other legally protected secrets in accordance with the Law of Ukraine "on state secrets" and "on information", and for non - disclosure of confidential and private information-five years after retirement from public service.

In The code of conduct it should also be noted that the employee as a General rule should not use the information obtained in the course of the performance of official duties, the disclosure of which is prohibited both in their own interests and in the interests of other persons, except for cases when such use is aimed at preventing a real threat to life or health of people ${ }^{10}$.

\section{Problems of systematization of legislation on public service}

The civil service is a multi-element legal institution. Most of the legal norms regulating it are now concentrated in administrative law. The legislation of Ukraine on civil service is considered a sub-branch of administrative legislation.

The systematization of administrative legislation, part of which is the legislation on public service, is an extremely urgent problem now. Systematization of this legislation is quite a difficult task. This is explained to some extent by the fact that, first, it is now the law consists of the basic legislative act - the law of Ukraine "On civil service" of 1993 (hereinafter the

\footnotetext{
${ }^{9}$ On the Cabinet of Ministers of Ukraine: Law of 07.10.2010. Sheets of the Verkhovna Rada of Ukraine from 04.03.2011. No. 9, page 429, article 58/

${ }^{10}$ About public service: the Law of Ukraine of 10.12.2015. Sheets Of The Verkhovna Rada. 2016. No. 4. P. 43.
} 
current Law), as well as from a large number of regulations - more than twenty decrees of the President of Ukraine and over a hundred resolutions of the Cabinet of Ministers of Ukraine (hereinafter - regulations); secondly, the full systematization of this legislation in the past period was not carried out.

At the same time, the legislation on public service does not correspond to many norms-regulations of the Constitution of Ukraine, it is obsolete, cumbersome, regulations largely inconsistent and the like. In particular, the still ongoing practice of trying to settle the relations of the public service regulations, despite the fact that the Constitution requires the organization and activities of bodies of Executive power, the fundamentals of state service" was defined exclusively by laws (paragraph 12 of part one of article 92). A serious drawback is the conceptual focus on the regulation of public-service relations arising in connection with and about the passage of public service, mainly by private legal means inherent in labor law, and the diminution of the value of public-legal means inherent in administrative law. There is also a lack of system of the whole array of different legal nature of the acts devoted to public service, which led to the parallel existence of different types of public service, the development of which in conceptual terms, in our opinion, should be based on common principles and approaches. As rightly pointed out in this regard, V. Averyanov, the current Law of Ukraine "on public service" does not systematically solve the conceptual issues of creating an integral Institution of public service in our state ${ }^{11}$.

Systematization of legislation should be carried out by its inherent methods. As is known, systematization is carried out in the form of incorporation and codification. Therefore, it is necessary to determine the priority way to systematize the legislation of Ukraine on public service.

In the course of the forthcoming systematization of legislation on public service, it is necessary to focus on the main thing-the release from outdated acts and the preparation of a new legislative act, the replacement of contradictory norms and constipation in such a new act of progressive legal structures, the elimination of legal gaps by offering modern scientific views and approaches.

To do this, it is necessary to focus on codification. Incorporation should be given a supporting role - to conduct an ongoing review of legal acts for the removal of no longer existing provisions and making appropriate additions.

So, despite the fact that the civil service is a special institution of the modern state, it is necessary to codify the legislation of Ukraine on public service.

${ }^{11}$ On the Central bodies of Executive, power the Law of 17.03.2011. Official Visnik Ukrainy vid 18.04.2011. No. 27, p. 320 , article 1123 
As it is known, the basic codification acts include: fundamentals of legislation-normative legal acts that establish the most important provisions (basic principles) of a certain branch of law or the sphere of state administration; code-the most common type of codification acts acting in the main spheres of public life that require legal order; Charter, regulationscodification acts of special action, which are adopted not only by legislative but also law-making bodies (for example, the government).

In preparation for the systematization, it should be borne in mind that the codification of legislation on public service is a complex problem of legal science. The fact is that various branches of law regulate the institution of public service simultaneously, in particular such as constitutional, administrative, labor, financial, civil, and criminal and the like. At the same time, administrative law exerts the most significant influence on the civil service. It is no coincidence that today the civil service is considered as a subbranch of administrative law.

The process of codification is quite complex and painstaking work, in particular because it involves such three stages as: identification of legislative shortcomings of a particular industry (sub-sector); elimination of such shortcomings by means of law and legal technology; bringing the processed material into a single whole in order to consolidate it at the legislative level.

The basis for the codification of the legislation on public service should already be taken at the highest state level political decisions on the need for state law reform in Ukraine and on the assignment of the basic provisions of the Concept of administrative reform in Ukraine as the basis for the implementation of the reform of the public administration system. This Concept, in particular, provides that, first, it is necessary to revise the legislation in relation to the public service. Along with amendments to the current Law of Ukraine "on public service" and improvement of existing legal acts, "in the future, it is necessary to adopt a generalizing law that would serve as a methodological and regulatory Foundation for the legal support of an integral Institution of public service, taking into account all the features at different stages of its development."

Codification is primarily subject to those institutions of public service that are insufficiently regulated by the current Law, their regulation is carried out not by Law, but by bylaws, or they are still regulated by other branches of law.

Such codification should be aimed at overcoming existing contradictions and inconsistencies in the current legislation, based on modern scientific ideas about the Institute of public service with its inherent features and prospects for improvement. 


\section{CONCLUSIONS}

Since the entire system of public service of Ukraine is subject to reform, we focus only on the main unresolved problems that need to be eliminated as a result of codification.

First, the scope of the institution of public service in Ukraine requires a clear definition. For this purpose, it is necessary, at last, to get rid of terminological uncertainty and as soon as possible legislatively to fix concept "the civil servant", "the state position of public service", and to specify value of the basic term "public service". At the same time, it is necessary to take into account the terminological divergence of the content of the concepts of "work" and "service". This will help to determine the broad and narrow understanding of the concept of "public service" in favor of one of them. In particular, we propose to choose a narrowed approach. That is to consider as civil servants only those persons who professionally and for the state means carry out tasks of public administration and state regulation on positions of public service in public bodies of their office. It should also be borne in mind that the terms "public service", "public sector", "public sector" cannot coincide.

Secondly, it is necessary to move to the legal regulation of public service and legal relations arising in connection with its passage by civil servants of state bodies and their apparatuses, methods of public law inherent in administrative, constitutional and other public branches of law, and at the same time to stop the use of private law methods inherent in civil and labor law. That is, the legal relations of the civil service should be regulated not by labor, but by administrative law.

Scientists have already made various proposals, including those that are quite difficult to agree on the ways and methods of codification of legislation on public service, as well as the form of future codified acts. For Example, V. Would. Averyanov believes that this may be the fundamental Law of Ukraine "on the basics of service in the state", which would include: General provisions inherent in all categories of civil servants; comprehensive classification of civil servants; regulation of the organization of management of the civil service, etc.

\section{SUMMARY}

The main directions of reforming the civil service at the present stage. Types of public service: problems of classification. Problems of legal regulation of behavior and disciplinary responsibility of civil servants. Problems of systematization of legislation on public service. 


\section{REFERENCES}

1. Constitution of Ukraine: Adopted by the Verkhovna Rada of Ukraine on June 28, 1996. 1996. No. 30. P. 141.

2. Code of Ukraine on administrative offences: Enacted by the Supreme Council of the Ukrainian SSR from 07.12.1984. Bulletin of the Supreme Rada of the Ukrainian SSR. 1984. Annex to No. 51. P. 1122.

3. About public service: the Law of Ukraine of 10.12.2015. Sheets Of The Verkhovna Rada. 2016. No. 4. P. 43.

4. On the Cabinet of Ministers of Ukraine: Law of 07.10.2010. Sheets of the Verkhovna Rada of Ukraine from 04.03.2011. No. 9, page 429, article 58.

5. On the Central bodies of Executive power: the Law of 17.03.2011. Official Visnik Ukrainy vid 18.04.2011. No. 27, p. 3 20, article 1123.

6. About local state administrations: the Law of Ukraine of 09.04.1999. Sheets of the Verkhovna Rada of Ukraine of 28.05.1999. No. 20, article 190.

7. About measures for introduction Of the concept of administrative reform in Ukraine: the Decree of the President of Ukraine No. 810 of 22.07.1998. Official journal of Ukraine. 1999. No. 21. P. 943.

8. Administrative law of Ukraine. Academic course: Textbook: in 2 t. / Vidpovid. ed. Averyanov: Vol. 1: General part. Kyiv: legal opinion, 2007. 591 c. T. 2: special part. Kyiv: Yuridichna Dumka, 2009. 600 s.

9. Bityak Y. Civil service in Ukraine: organizational and legal basis. Kharkiv: Pravo, 2005. 304s.

10. Kolpakov V. Administrative law of Ukraine: Textbook, third edition, augmented. Kiev, Yurinkom Inter, 2001. 752 p.

11. Kravchenko S. state-management reforms: theoretical and methodological justification and directions of implementation: monograph. Kyiv: NAGU, 2008. 296c.

12. Tsurkan M. legal regulation of public service in Ukraine. Features of litigation disputes: monograph. Kharkiv: Pravo, 2010. 216 p.

\section{Information about the author:} Chebotareva G. V.,

Doctor of Law, Professor, Professor of the Department of Administrative,

Criminal Law and Procedure, International University of Business and Law 37-A, 49 HGD str., Kherson, 73040, Ukraine 